\title{
Application of a Yeast Biosurfactant in the Removal of Heavy Metals and Hydrophobic Contaminant in a Soil Used as Slurry Barrier
}

\author{
R. D. Rufino, ${ }^{1,2}$ G. I. B. Rodrigues, ${ }^{3}$ G. M. Campos-Takaki,, 2 \\ L. A. Sarubbo, ${ }^{1,2}$ and S. R. M. Ferreira ${ }^{1,3}$ \\ ${ }^{1}$ Centre of Science and Technology, Catholic University of Pernambuco, Rua do Príncipe, No. 526, Boa Vista, \\ 50050-900 Recife-Pernambuco, Brazil \\ ${ }^{2}$ Centre of Research in Environmental Sciences, Catholic University of Pernambuco, Rua Nunes Machado, No. 42, Bl J, \\ Térreo, Boa Vista, 50050-590 Recife-Pernambuco, Brazil \\ ${ }^{3}$ Centre of Technology, Federal University of Pernambuco, 500670-420 Recife-Pernambuco, Brazil \\ Correspondence should be addressed to \\ L. A. Sarubbo, leonie@unicap.br
}

Received 15 June 2011; Revised 6 August 2011; Accepted 16 August 2011

Academic Editor: Andrea Franzetti

Copyright () 2011 R. D. Rufino et al. This is an open access article distributed under the Creative Commons Attribution License, which permits unrestricted use, distribution, and reproduction in any medium, provided the original work is properly cited.

This work describes the application of a yeast biosurfactant in the removal of heavy metals and petroleum derivate in a soil used as slurry barrier using a triaxial permeability apparatus. Test specimens were prepared with soil and contaminants for percolation of the biosurfactant. The hydraulic conductivity measured along percolation of the fluids showed that the biosurfactant reduced significantly the soil permeability, demonstrating its applicability as an additive in reactive barriers. The crude biosurfactant removed around $96 \% \mathrm{Zn}$ and $\mathrm{Cu}$ and reduced the concentrations of $\mathrm{Pb}, \mathrm{Cd}$, and $\mathrm{Fe}$ from the test specimen. The biosurfactant removed $20 \%$ of the waste oil using the permeability apparatus. The results show that the biosurfactant can be applied in new technologies where the removal of heavy metals and petroleum derivates is desirable. These results demonstrate the versatility of biomolecules with amphipathic nature, a property that makes them increasingly competitive with real possibilities for use in industries.

\section{Introduction}

With the growth of industrial production, many products are improperly accumulated in the environment, contaminating soil and groundwater. Water and soil contaminants include inorganic species such as nitrate and phosphate, heavy metals like cadmium, chromium, mercury, and lead, and organic chemicals, including hydrophobic compounds, inorganic acids and radionuclides [1]. In the natural soil, these contaminants cannot be completely degraded and may be more or less mobile in the soil [2].

The Brazilian Association of Standard Methods (ABNT) defines slurry as a "liquid produced by the decomposition of substances in urban solid residues which features a dark color, a bad smell and a high BOD (Biochemical Oxygen Demand); it constitutes a mixture of organic and inorganic compounds in solution and in colloidal state and of several microorganisms species" [3]. The generation of slurry in a landfill is due to the percolation of rainwater infiltrating the landfill and the coverage that exceeds the capacity of the soil to retain the water in its pores (field capacity).

Several physicochemical and biological methods, or a combination of both, are used to treat slurry. According to Gomes [4], the biological process allows the biodegradation of organic compounds in slurry by the action of microorganisms that turn them into simpler substances as water, carbon dioxide, and methane. The physical-chemical treatment combined with biological treatment, instead, can eliminate the undesirable leaching of chemical species in the effluent, such as heavy metals and organic compounds. In the physical-chemical treatments, on the other hand, the main techniques used are dilution, filtration, coagulation, 
flocculation, precipitation, sedimentation, adsorption, ion exchange, chemical oxidation, reverse osmosis, air washing, ultrafiltration, oxidation, natural evaporation, and vaporization.

Among the main methods to treat slurry, the technique of reactive barriers consists of a passive treatment in which the liquid being treated passes through the interior of the barrier (or reactors) that contains a material that provides a specific treatment. It is usually a physical-chemical process, where the reactors, in general, consist of soil or mixtures of the soil with other reactive materials. A Permeable Reactive Barrier (PRB) is a treatment zone of reactive material(s) that is built below ground to clean up polluted groundwater. The reactive zone may be installed as a wall to intercept a migrating plume of contaminated groundwater. Alternatively, the contamination can be funnelled by low permeability barriers (e.g., slurry walls) to a gate or vessel containing the reactive media [5]. Typically, this treatment process is passive, driven only by the natural condition of the groundwater flow. For this reason, the technique of permeable reactive barriers, if any, constitutes an alternative remediation of contaminated areas with operational simplicity and economic advantages over other techniques.

This study is focused on the use of the technique of permeable reactive barrier in the treatment of the slurry generated within a landfill. Some of the most important processes include precipitation, sorption, oxidation/reduction, fixation, and degradation. These processes may occur simultaneously to absorb the pollutants from the groundwater or to convert harmful chemicals to harmless byproducts $[6,7]$. It is thus necessary to know the characteristics of the contaminant to select the type of reactive element to the most appropriate treatment. Different contaminants have different behaviors and characteristics which requires reactive barriers to be constructed specifically for each contaminant. This involves reactive efficiency criteria, cost, material availability, feasibility, and the byproduct generated, among other operational constraints. Some important factors that limit the application of the technique include the depth at which the plume of contamination occurs, the density of the contaminant, and the thickness of the aquifer. The technique of permeable reactive barrier is applied to relatively low depths, as very deep permeable reactive barriers are uneconomic due to spending on excavation, mobilization of land, and maintenance of the barrier, among others. The permeability of the barrier becomes another important factor. The permeability of the barrier has to be such that the flow through the barrier can be slow enough so that reactions occur, and at the same time, should be greater than or equal to the natural water flow so that the barrier does not create a speed reduction of the natural flow, resulting in the deviation of the contamination plume.

A series of reactive materials has been analyzed for remediation and/or degradation of different compounds, including inorganic contaminants such as heavy metals and organic contaminants, oils, and industrial solvents [7]. Examples of reactive media are activated carbon for absorption of organics, ion exchange resins for adsorption of metals and radionuclides, zero valent iron for dechlorination of halogenated solvents, absorption of carbon disulphide or reduction of oxymetal ions (e.g., chromate), limestone for precipitation of metals, and sand/gravel beds with the addition of nutrients and oxygen to promote microbial degradation of organic contaminants.

In this context there is the possibility of applying biosurfactants as reactive elements in the treatment of contaminants contained in reactive barriers, technique as far we know not previously described in the literature.

Surfactants are chemical compounds consisting of amphipathic molecules containing hydrophilic and hydrophobic portions that partition preferentially at the interface between fluid phases that have different degrees of polarity and hydrogen bonding, as oil/water or air/water interfaces. The nonpolar portion is often a hydrocarbon chain, and the polar portion can be ionic (cationic or anionic), nonionic, or amphoteric [8]. These features allow surfactants to reduce surface and interfacial tension and forming microemulsions where the oil can be solubilized in water or where water can be solubilized in hydrocarbons [9]. These properties enable a wide range of industrial applications involving detergency, emulsification, lubrication, foaming capacity, wettability, solubilization, and phases dispersion.

Considering that few technologies can be used together in the treatment of organic pollutants and heavy metals, the biosurfactants, depending on their properties, can be applied not only in the removal of hydrophobic organic compounds, as well as in the removal of heavy metals. Biosurfactants act reducing the interfacial tension and solubilizing hydrocarbons in the aqueous phase or via the capture of oil droplets within their micelles, while biosurfactants of anionic nature can also capture the metal ions through electrostatic interactions or complexation [10].

The objective of this study was to investigate the applicability of a yeast biosurfactant that shows excellent surfactant properties [11] in the treatment of contaminants from municipal solid waste contained in a soil used as slurry barrier.

\section{Materials and Methods}

2.1. Soil. A barrier silty soil was utilized in the experiments. The soil was collected from Abreu e Lima City, in Pernambuco state, Brazil. Samples of the soil $(5 \mathrm{Kg})$ were homogenized and left to stand at room temperature for four days to dry and finally stored for later use.

2.2. Waste Oil of Car Engine. The lubricant motor oil was obtained from a local automotive workshop and used as the soil contaminant.

2.3. Physical-Chemical Characterization of the Soil. The analyses were carried out based on the Brazilian Association of Standard Methods (ABNT). All samples were submitted to grain size analysis [12], liquid limit [13], and plasticity [14], particles specific weight [15], and compression determination [16].

The chemical characterization of the sieved soil, before and after percolation of the contaminants and fluids tested, 
was conducted in the Chemistry Laboratory from Catholic University of Pernambuco, Brazil. Analyses of exchangeable cations $\left(\mathrm{Ca}^{2+}, \mathrm{Mg}^{2+}, \mathrm{Na}^{+}, \mathrm{K}^{+}, \mathrm{Al}^{3+}\right.$, and $\left.\mathrm{H}^{+}\right)$, organic $\mathrm{C}$ content, $\mathrm{pH}$ in $\mathrm{H}_{2} \mathrm{O}$ and $\mathrm{KCl}$, electric conductivity, and specific surface were performed by the Soil Analysis Methods Manual from Embrapa, Brazil [17]. According to the results obtained the sum of bases, the cationic exchange capacity, the bases saturation grade, the aluminum saturation, and the saturation by sodium and oxides were calculated.

2.4. Soil Samples Preparation. The soil was air dried, passed through a 50 mesh $(0.297 \mathrm{~mm}$ opening), and mixed with tap water to a water content of $19 \%$ (natural soil).

To simulate a contamination of the waste oil of car engine in the soil and subsequent compaction of the test specimen, it was necessary to proceed with manual homogenization of the two phases. The quantity of oil was determined as a function of the dry weight of the soil sample (10\%).

The natural soil and the mixture of soil plus waste oil were statically compacted (optimal water content of 19 and $13 \%$, resp.) using a standard Proctor method [16] at a specific dry weight of $16.00 \mathrm{KN} / \mathrm{m}^{3}$, extruded from the compaction mold, and trimmed to a diameter of $98 \mathrm{~mm}$ using a thin walled sharp edge pipe. The trimmed soil had a height of $109 \mathrm{~mm}$.

The soils chemical analyses were performed in the inflow and outflow of each test specimen percolated by the contaminants. The site of sectioning was defined as the midpoint orthogonal to its height, parallel to this stream.

The description of the specimens and their proper contamination and percolates is shown in Table 1 .

2.5. Biosurfactant. The crude biosurfactant produced by Candida lipolytica (UCP 0988) was used as percolate in the removal of the contaminants. The biosurfactant was produced in a mineral medium containing $6 \%$ of soybean oil refinery residue and $1 \%$ glutamic acid during 72 hours under orbital shaking at $150 \mathrm{rpm}$. After cultivation, the broth containing metabolites was centrifuged at $2000 \times \mathrm{g}$ and the cellfree broth was used as the crude biosurfactant. The anionic biosurfactant exhibits excellent surface activity, reducing the water surface tension from $71 \mathrm{mN} / \mathrm{m}$ to $25 \mathrm{mN} / \mathrm{m}$. The preliminary chemical characterization of the biosurfactant indicated the presence of 50\% protein, $20 \%$ lipid, and $10 \%$ carbohydrates, as previously described by Rufino et al. [11].

2.6. Slurry. The natural slurry was obtained from the Aguazinha landfill, located in Olinda city, Pernambuco state, Brazil. The Aguazinha landfill get daily on average 400 tonnes of municipal solid waste, bulky solids (debris and sweeps) and pruning waste corresponding to a total of approximately 12,000 tonnes per month [18]. The chemical characterization of the slurry was held in the Chemical Engineering Laboratories from Federal University of Pernambuco, according to APHA [19]. The slurry was used as a soil percolate.

2.7. Hydraulic Conductivity Test. The hydraulic conductivities of the saturated soils, percolated by $500 \mathrm{~mL}$ of distilled
TABLE 1: Test specimens and percolates used in the experiments.

\begin{tabular}{ll}
\hline $\begin{array}{l}\text { Identification of } \\
\text { test specimens }\end{array}$ & Percolate types \\
\hline NS & $\begin{array}{l}\text { Natural soil (soil before percolation of } \\
\text { contaminants) }\end{array}$ \\
\hline S-DW & Soil percolated by distilled water \\
\hline S-SL & Soil percolated by the slurry \\
\hline S-WO & $\begin{array}{l}\text { Soil resulting from the mixture of soil and } \\
\text { waste oil of car engine }\end{array}$ \\
\hline S-WO-B & $\begin{array}{l}\text { Soil resulting from the mixture of soil and } \\
\text { waste oil of car engine, percolated by the } \\
\text { biosurfactant }\end{array}$ \\
\hline S-SL-B & $\begin{array}{l}\text { Soil percolated by the slurry followed by the } \\
\text { biosurfactant }\end{array}$ \\
\hline
\end{tabular}

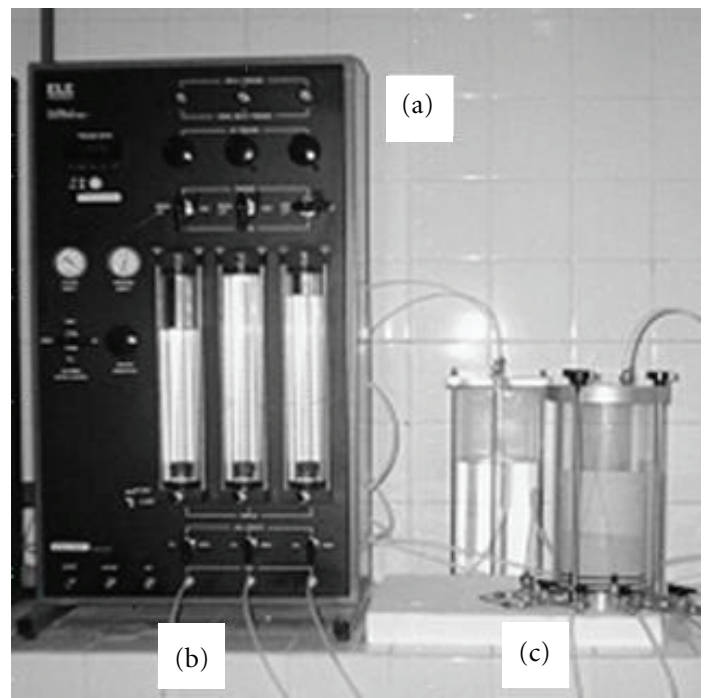

Figure 1: Permeability test system. (a) Pressure control panel. (b) Flow control. (c) Specimen.

water, $500 \mathrm{~mL}$ of slurry, and $500 \mathrm{~mL}$ of biosurfactant were determined in a permeability test system (Figure 1).

After preparation of each test specimen it was mounted in the permeability cell. The sample was then saturated using a backpressure, and the applied pressure was $120 \mathrm{kPa}$. This pressure was maintained for 24 hours to ensure complete saturation of the sample, being evidenced by the parameter $\bar{B}\left(\bar{B}=\Delta u / \Delta \bar{\sigma}_{3}=1\right.$, where $\Delta u$ is the increase porewater pressure and $\Delta \bar{\sigma}_{3}$-confining pressure increase), using a transducer with reading external pressure. Between each step and after consolidation, the hydraulic conductivity was determined. To establish the flow of water, for the slurry or the biosurfactant in the sample, it was applied a voltage difference between the bottom and the top of $5 \mathrm{kPa}$, when it was measured the time a water volume of $5.000 \mathrm{~mm}^{3}$ takes to cross the test specimen. The volumes of inflow and outflow were recorded and plotted against the elapsed time. When the rates of inflow and outflow became equal, the final hydraulic conductivity values were calculated based on Darcy's law. 
In the experiment with distilled water, for the test specimen S-DW, used as the physical-chemical reference, it was not necessary to modify the equipment, because the fluid can pass without any wear, through the internal components of the permeameter.

The slurry and the waste oil, on the other hand, cannot percolate inside the equipment, considering their huge aggression to the components of the equipment. Thus, it was used a basal tension equal to zero and the contaminant only percolated through the helper cell permeameter. In all tests the soil was saturated with the respective contaminant before starting the measurement of the hydraulic conductivity. The exception occurred in the test specimen S-WO-B, to which the contaminant was inserted before the soil compaction and the fluid saturation was made by the biosurfactant. The additional percolation of the biosurfactant was done in order to evaluate its ability to decontaminate the test specimens $\mathrm{S}$ WO-B and S-SL-B.

2.8. Heavy Metals Determination in the Soil Samples. The soil samples were analyzed for heavy metals $(\mathrm{Fe}, \mathrm{Cd}, \mathrm{Zn}, \mathrm{Cu}$, and $\mathrm{Pb}$ ) before and after percolation of the fluids by flame atomic absorption spectrophotometry using a Varian AA220 FS instrument. Samples were analyzed for heavy metals before and after percolation of the fluids.

2.9. Waste Oil of Car Engine Removal from the Soil Sample. The waste oil of car engine removed after percolation of the biosurfactant in the test specimen S-WO-B was analyzed in the outflow section by extraction of the removed oil with hexane followed by quantification of the removal percentage by gravimetric determination. Liquid-liquid extractions of the samples were performed using hexane because the biosurfactant is not soluble in the hexane, as described by Rufino et al. [11].

\section{Results and Discussion}

3.1. Physical Characterization of the Soil. The use of soil as a permeable reactive barrier for the in situ remediation treatment requires, first, the proper characterization of the soil. The physical and chemical properties of soil are important in determining its applicability in reactive barriers by containing and directing the hydraulic flow of the plume and as a component element of the reactive part.

The results of soil particle size and of compaction using the Standard Proctor method are presented in Table 2.

The size distribution showed a predominance of fine fraction in the soil. The soil was classified as moderately plastic-PI between 7 and 15 [20]. The activity index of 0.4 indicated the clay inactive fraction. Classification by the Unified Soil Classification falls as a clay of low compressibility (LC).

After mixing between soil and oil, it was performed a compression test. An optimum moisture content of $13.20 \%$ and a maximum dry weight of $16.90 \mathrm{kN} / \mathrm{m}^{3}$ were obtained. It was observed that there was a reduction in the value of the optimum moisture of the natural soil when the oil was added
TABLe 2: Size distribution, consistence, and soil unified classification.

\begin{tabular}{|c|c|}
\hline \multicolumn{2}{|c|}{ Size distribution $(\%)$} \\
\hline Sandy & 41 \\
\hline Silty & 17 \\
\hline Clay & 42 \\
\hline$\%<2 \mu \mathrm{m}$ & 24 \\
\hline \multicolumn{2}{|c|}{ Consistence } \\
\hline Liquid limit (\%) & 38 \\
\hline Plasticity index (\%) & 14 \\
\hline $\mathrm{Ia}^{\mathrm{a}}$ & 0.48 \\
\hline \multicolumn{2}{|c|}{ Compaction } \\
\hline Optimum moisture content (\%) & 19.0 \\
\hline$\rho_{\mathrm{d} \max } \mathrm{b}\left(\mathrm{kN} / \mathrm{m}^{3}\right)$ & 16.9 \\
\hline Unified Classification & $\mathrm{LC}$ \\
\hline
\end{tabular}

and no change was observed in the value of the maximum dry weight of the soil. The oil acted as a lubricant, reducing the friction between the particles thus making the mixture soil-oil to have the same maximum dry specific weight for the same applied energy.

3.2. Chemical Characterization of the Soil. The chemical characteristics of the natural soil are described in Table 3. The soil has pronounced acidity, with $\mathrm{pH}$ ranging between 4.0 and 5.2. The difference between $\mathrm{pH}_{\mathrm{KCl}}$ and $\mathrm{pH}_{\mathrm{H}_{2} \mathrm{O}}$ was negative, indicating the presence of silicate clays [21]. The soil has no organic matter. This can be explained by the depth at which the soil sample was collected ( $7 \mathrm{~m}$ underground). The cation exchange capacity is low. The base saturation indicated that the soil is fertile for planting. The electrical conductivity of the natural soil was low, with a low salt content in its constitution. Considering the levels of ferric oxide $\left(\mathrm{Fe}_{2} \mathrm{O}_{3}\right)$ the soil has low iron content. The value found for the specific surface confirmed the presence of the mineral kaolinite in the mineralogy of the natural soil.

3.3. Hydraulic Conductivity. The hydraulic conductivity coefficient is defined as the greater or lesser ease with which water passes through a physical medium. The results of the hydraulic conductivity are presented in Table 4 . The hydraulic conductivity of the soil with distilled water taken by reference in this work is $3.61 \times 10^{-9} \mathrm{~m} / \mathrm{s}$, typical of clay and excellent to act as an impermeable barrier. In the case under study, there are small variations in the soil hydraulic conductivity when making percolation of the fluids. All conductivities are of the same order of magnitude $\left(10^{-9} \mathrm{~m} / \mathrm{s}\right)$ except in soil mixed with oil (S-WO). The ratio between the conductivity of percolating and distilled water $\left(\mathrm{K}_{\mathrm{pf}} / \mathrm{K}_{\mathrm{dw}}\right)$ was higher when water percolated the soil mixed with the waste oil (S-WO) and lower when the biosurfactant percolated the same specimen.

The conductivity of the soil saturated with the slurry was reduced when the biosurfactant had percolated it, reaching levels of $10^{-10} \mathrm{~m} / \mathrm{s}$. 
TABle 3: Chemical characterization of the natural soil.

\begin{tabular}{|c|c|}
\hline Determination & Values \\
\hline $\mathrm{pH}$ in $\mathrm{H}_{2} \mathrm{O}$ & 5.20 \\
\hline $\mathrm{pH}$ in $\mathrm{KCl}$ & 4.04 \\
\hline Organic matter $(\mathrm{g} / \mathrm{Kg})$ & 0.00 \\
\hline Extractable aluminum $\left(\mathrm{Al}^{+++}\right)$ & 0.35 \\
\hline Exchange $\mathrm{Ca}^{++}(\mathrm{cmol} / \mathrm{kg})$ & 0.00 \\
\hline Exchange $\mathrm{Mg}^{++}(\mathrm{cmol} / \mathrm{kg})$ & 5.80 \\
\hline Exchange $\mathrm{Na}^{+}(\mathrm{cmol} / \mathrm{kg})$ & 7.60 \\
\hline Exchange $\mathrm{K}^{+}(\mathrm{cmol} / \mathrm{kg})$ & 0.50 \\
\hline sodium saturation $(\%)$ & 54.50 \\
\hline Sum of cations $(\mathrm{cmo} / \mathrm{kg})$ & 13.94 \\
\hline Extractable hydrogen $\left(\mathrm{H}^{+}\right)(\mathrm{cmol} / \mathrm{kg})$ & 5.85 \\
\hline Cation exchange capacity $(\mathrm{cmol} / \mathrm{kg})$ & 20.14 \\
\hline Saturation of base (\%) & 69.21 \\
\hline $\mathrm{Fe}_{2} \mathrm{O}_{3}$ in the sulfuric extract $(\%)$ & 4.63 \\
\hline $\mathrm{SiO}_{2}$ in the fine soil (\%) & 73.0 \\
\hline $\mathrm{Al}_{2} \mathrm{O}_{3}$ in the sulfuric extract (\%) & 13.0 \\
\hline Water in the saturated extract (\%) & 44.2 \\
\hline Electric conductivity in the saturated extract $(\mu \mathrm{S} / \mathrm{cm})$ & 0.012 \\
\hline Specific surface $\left(\mathrm{m}^{2} / \mathrm{g}\right)$ & 14.7 \\
\hline
\end{tabular}

The oil mixed with the soil caused an initial increase in conductivity compared to the natural soil with distilled water and the biosurfactant reduced progressively the effect of oil after 20 days under observation.

Accordingly, the hydraulic conductivity showed that the biosurfactant was able to markedly reduce the permeability of the soil, thus allowing its application as an additive in reactive barriers. The ionic nature of the biosurfactant increased the attraction between charged particles, causing the soil structure to become less porous and thus hindering percolation of the fluids.

3.4. Removal of Heavy Metals from the Soil Samples. Surfactants, especially biosurfactants, usually possess excellent surface active properties, anionic nature, and low toxicity. Through adsorbing onto sediment surface, complexing with metal, detaching the metal from the sediment into the porewater, and hence associating with surfactant micelles, surfactants can effectively remove the metals adsorbed on sediment particles [22].

The possible mechanisms for the extraction of heavy metals by biosurfactants are ion exchange, precipitationdissolution, and counterion binding. The anionic biosurfactant carries a negative charge, so when the molecule encounters a cationic metal that carries a positive charge, an ionic bond is formed. This bond is stronger than the metal's bond with the soil [23]. Metal ions are bound to oppositely charged ions or replace the same charged ions (electrostatic interactions or ion exchange) or complex with agents forming chelates on the micelle surface. The polar head groups of micelles can bind metals. This makes the metals more soluble in water. Surfactant monomers likely acted to solubilize adsorbed metals through formation of dissolved complexes. In addition, some binding of the metal may occur to the anionic exterior of surfactant micelles. Surface tension will predominately influence sorption that occurs through hydrophobic interactions such as partitioning of nonionic organic compounds rather than metals. However, it is also postulated that the metals are removed by forming complexes with the biosurfactants on the soil surface, being detached into the soil solution due to the lowering of the interfacial tension, and hence associating with surfactant micelles. Soil composition, clay mineralogy, permeability, $\mathrm{pH}$, cation exchange capacity, particle size, and other factors such as the presence of competing ligands, the ionic strength of the soil, and the simultaneous presence of competing metals and contaminants significantly affect sorption-desorption processes and leaching potential through a soil profile [23, 24].

Biosurfactants used for soil treatment are also required to have minimal sorptive interactions applied to the soil system; in other words, most of the biosurfactant should remain in the aqueous phase. Biosurfactant sorption in general is likely the reason that high biosurfactant concentrations are required for effective metal removal $[23,24]$. Logically, the adsorptive behavior of a biosurfactant will depend on their molecular characteristics, such as charge and hydrophobicity, as well as on the soil characteristics.

In this sense, the low cost anionic biosurfactant produced from the cultivation of the yeast Candida lipolytica in soybean refinery residue, capable of reducing the surface tension of water to $25 \mathrm{mN} / \mathrm{m}$, was tested in the removal of heavy metals contained in specimens contaminated with engine lubricating oil and slurry in a permeability apparatus.

The tests of flame atomic absorption spectrometry conducted in the natural soil and in the tested specimens S-SL, S-SL-B, and S-WO-B are shown in Table 5. All comparisons made of increasing and decreasing percentages were taken based on the levels of each metal in the natural soil.

For soil mixed with waste oil the percolation of the biosurfactant (S-WO-B) caused a reduction in the iron concentration around $16.5 \%$ and in cadmium concentration of $50 \%$ in the outflow section of the specimen. With respect to zinc, there was an increase in the concentration of this metal, showing that the biosurfactant concentrated it in the specimen outflow. In the case of copper and lead, on the other hand, there was a displacement of these metals to the outflow section of the soil, thus increasing their concentrations at 20 and $17 \%$, respectively.

For the soil percolated by the slurry (S-SL), no changes were observed in the concentrations of metals on the top (inflow section), except with respect to copper and lead, which were reduced by 46 and 13\%, respectively.

For the soil percolated by the slurry and subsequently by the biosurfactant (S-SL-B), there was an increase in the concentration of iron and cadmium in the base (outflow section) of the test specimen over the top, although the values found are below the respective concentrations of these metals in the natural soil. For zinc and copper, it was observed a reduction of concentrations in the base of the specimen over the top of 96.2 and $96.8 \%$, respectively. To lead, it was 
TABLE 4: Hydraulic conductivity values in the test specimens.

\begin{tabular}{|c|c|c|c|c|c|}
\hline \multirow{2}{*}{ Values } & \multicolumn{5}{|c|}{ Test specimens } \\
\hline & S-DW ${ }^{\mathrm{b}}$ & $\mathrm{S}-\mathrm{SL}^{\mathrm{c}}$ & S-SL-B ${ }^{\mathrm{d}}$ & $S-W O^{e}$ & $S-W O-B^{f}$ \\
\hline Hydraulic conductivity $\mathrm{k}(\mathrm{m} / \mathrm{s})$ & $3.61 \times 10^{-9}$ & $5.91 \times 10^{9}$ & $2.46 \times 10^{-9}$ to $1.0 \times 10^{10}$ & $1.93 \times 10^{-7}$ & $1.43 \times 10^{-9}$ \\
\hline 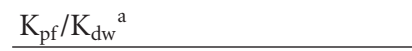 & 1 & 1.60 & 0.68 & 53.46 & 0.39 \\
\hline
\end{tabular}

TABLE 5: Release of metals from test specimens before and after percolation of the fluids.

\begin{tabular}{|c|c|c|c|c|c|c|c|}
\hline \multirow{3}{*}{ Heavy metals } & \multicolumn{7}{|c|}{ Quantification of heavy metals in the test specimens } \\
\hline & \multirow{2}{*}{ Soil (g/kg) } & \multicolumn{2}{|c|}{ S-WO-Ba $(g / k g)$} & \multicolumn{2}{|c|}{$\mathrm{S}-\mathrm{SL}^{\mathrm{b}}(\mathrm{g} / \mathrm{kg})$} & \multicolumn{2}{|c|}{$\mathrm{S}-\mathrm{SL}-\mathrm{B}^{\mathrm{c}}(\mathrm{g} / \mathrm{kg})$} \\
\hline & & Inflow & Outflow & Inflow & Outflow & Inflow & Outflow \\
\hline $\mathrm{Fe}$ & $52.500 \pm 0,02$ & $51.705 \pm 0,02$ & $43.850 \pm 0,03$ & $48.075 \pm 0,01$ & $48.080 \pm 0,02$ & $44.500 \pm 0,03$ & $40.985 \pm 0,02$ \\
\hline $\mathrm{Cd}$ & $0.0009 \pm 0,02$ & $0.0012 \pm 0,01$ & $0.0006 \pm 0,02$ & $0.0010 \pm 0,03$ & $0.0010 \pm 0,02$ & $0.0005 \pm 0,01$ & $0.0007 \pm 0,01$ \\
\hline $\mathrm{Zn}$ & $0.0191 \pm 0,02$ & $0.0147 \pm 0,02$ & $0.1485 \pm 0,01$ & $0.0144 \pm 0,02$ & $0.0144 \pm 0,01$ & $0.3616 \pm 0,02$ & $0.0137 \pm 0,02$ \\
\hline $\mathrm{Cu}$ & $0.0133 \pm 0,02$ & $0.0128 \pm 0,03$ & $0.0154 \pm 0,02$ & $0.0076 \pm 0,01$ & $0.0041 \pm 0,01$ & $0.1615 \pm 0,02$ & $0.0051 \pm 0,02$ \\
\hline $\mathrm{Pb}$ & $0.0140 \pm 0,02$ & $0.0120 \pm 0,02$ & $0.0140 \pm 0,01$ & $0.0150 \pm 0,02$ & $0.0130 \pm 0,02$ & $0.0130 \pm 0,01$ & $0.0170 \pm 0,01$ \\
\hline
\end{tabular}

S-WO-Ba : soil resulting from the mixture of soil and waste oil, percolated by the biosurfactant; ${\mathrm{S}-S L^{\mathrm{b}}}^{\mathrm{a}}$ : soil percolated by the slurry; S-SL-B : soil percolated by the slurry followed by the biosurfactant.

observed that there was a shift of the metal to the base of the test specimen of $15.4 \%$.

The results showed that the biosurfactant was found to be effective for use in bioremediation mainly of zinc and copper for the treatment S-SL-B.

The concentration of the metals in the natural soil attended to the recommendations of the São Paulo State Environmental Company, Brazil, [25], except for the concentration of cadmium, which exceeded the limit of $0.0005 \mathrm{~g} / \mathrm{kg}$.

The possibility of the use of biosurfactants in the removal of heavy metals has been demonstrated in some studies conducted in laboratory scale.

The surfactant saponin, for example, which has a surface tension of $36 \mathrm{mN} / \mathrm{m}$, was tested at concentrations of 0.1 and $10 \%$. The removal of heavy metals in the soil was proportional to its concentration [26].

Mulligan et al. [27] demonstrated the applicability of biosurfactants in the removal of heavy metals in soils. The sophorolipid of Torulopsis bombicola grown in glucose and soybean oil, with a CMC of $0.8 \mathrm{~g} / \mathrm{L}(0.08 \%)$ and ability to reduce the surface tension to $34 \mathrm{mN} / \mathrm{m}$, was tested. The sophorolipid solution at $4 \%$ did not remove the $\mathrm{Zn}$ contained in the soil, removing only $3 \%$ of $\mathrm{Cu}$ while the rhamnolipid produced by Pseudomonas aeruginosa in mineral medium containing $4 \%$ glucose, with a $0.003 \%$ $\mathrm{CMC}$ and a surface tension of $26 \mathrm{mN} / \mathrm{m}$, allowed the removal of 20 and $35 \%$ of zinc and copper, respectively, at $12 \%$ concentration. The rhamnolipid solution at $2 \%$ removed only 5 and $10 \%$ zinc and copper, respectively.

Mulligan et al. [10] demonstrated the increased removal of $\mathrm{Zn}$ when $2 \%$ surfactin was used in combination with $\mathrm{NaOH}$. Daharazma and Mulligan [28] observed that the removal percentage of the heavy metals in the soil increased linearly with increasing concentration of the rhamnolipid tested. The use of $5 \%$ of the rhamnolipid removed $37 \% \mathrm{Cu}$, $7.5 \% \mathrm{Zn}$, and $33.2 \% \mathrm{Ni}$.

Two agents compatible environmentally, that is, a rhamnolipid $(0.5 \%)$ with a CMC of $0.005 \%(0.05 \mathrm{~g} / \mathrm{L})$ and carboxy methyl cyclodextrin (5.3\%), were tested for removal of metals adsorbed in two soil types. After ten successive washes, the rhamnolipid was able to remove 14.2 and $15.3 \%$ of $\mathrm{Pb}$ contained in the soils tested, while the carboxy methyl cyclodextrin removed 5 and $13.4 \%$ of this metal in the soils tested [29].

Since there are no reports in the literature for trials similar to those used in this work with the biosurfactant from Candida lipolytica (UCP 0988), it becomes difficult to discuss our results, although the percentage removal obtained can be considered satisfactory when compared to those reported in other experimental conditions as discussed above, since we used the cell-free broth containing the biosurfactant, that is the crude biosurfactant. The action of the surfactant was higher than the soil-contaminant interaction, since it was able to remove the heavy metals detected. Importantly, the depth of the soil significantly influenced the outcome of removal.

3.5. Removal of the Waste Oil of Car Engine. After percolation of the biosurfactant in the test specimen S-WO-B, the solution was analyzed to determine the content of oil removed. It was observed that the crude biosurfactant was able to remove $20 \%$ of the waste oil adsorbed to the soil. This result reflects the amphipathic properties of biosurfactants which allow these compounds to be used in simultaneous removal of different types of environmental contaminants such as heavy metals and hydrocarbons present in waste and spills of oil and derivates, as described by Mulligan et al. [10]. 


\section{Conclusions}

The results show that the biosurfactant can be applied with municipal solid waste barrier in reducing soil permeability and in the simultaneous recovery of heavy metals and hydrocarbons. The environmental compatibility and the possibility of combination with conventional methods of remediation drive the development of this alternative technology.

\section{Acknowledgments}

This work was financially supported by Coordination for the Improvement of Higher Level-or EducationPersonnel/Foundation for the Support of Science and Technology of the State of Pernambuco (CAPES/FACEPE), National Council for Scientific and Technological Development (CNPq), Catholic University of Pernambuco (UNICAP), Brazil, and Federal University of Pernambuco (UFPE), Brazil.

\section{References}

[1] D. L. Sparks, Environmental Soil Chemistry, Academic Press, San Diego, Calif, USA, 1995.

[2] D. S. Burden and J. L. Sims, Fundamentals of Soil Science as Applicable to Management of Hazardous Wastes, United States Environmental Protection Agency, Washington, DC, USA, 1998.

[3] ABNT, Associação Brasileira de Normas Técnicas. NBR 10.005: Procedimento para obtenção de extrato lixiviado de resíduos sólidos. Rio de Janeiro, Brazil, 2004.

[4] L. P. Gomes, Geração, características e processos relacionados ao chorume gerado pela degradação de resíduos sólidos urbanos. Revista do Centro de Ciências Exatas e Tecnológicas da UNISNOS. São Leopoldo, Brazil, 2000.

[5] S. S. Suthersan, Remediation Engineering: Design Concepts, Lewis publishers, Boca Raton, Fla, USA, 1996.

[6] R. C. Starr and J. A. Cherry, "In situ remediation of contaminated ground water: the funnel-and-gate system," Ground Water, vol. 32, no. 3, pp. 465-476, 1994.

[7] M. M. M. Nobre, "Estudos para execução de uma barreira reativa objetivando o controle da migração de uma pluma de mercúrio," 5o Congresso Brasileiro de Geotecnia Ambiental (REGEO '03), Porto Alegre, Brazil, 2003.

[8] C. Calvo, M. Manzanera, G. A. Silva-Castro, I. Uad, and J. González-López, "Application of bioemulsifiers in soil oil bioremediation processes. Future prospects," Science of the Total Environment, vol. 407, no. 12, pp. 3634-3640, 2009.

[9] K. Muthusamy, S. Gopalakrishnan, T. K. Ravi, and P. Sivachidambaram, "Biosurfactants: properties, commercial production and application," Current Science, vol. 94, no. 6, pp. 736-747, 2008.

[10] C. N. Mulligan, R. N. Yong, and B. F. Gibbs, "Surfactantenhanced remediation of contaminated soil: a review," Engineering Geology, vol. 60, no. 1-4, pp. 371-380, 2001.

[11] R. D. Rufino, L. A. Sarubbo, and G. M. Campos-Takaki, "Enhancement of stability of biosurfactant produced by Candida lipolytica using industrial residue as substrate," World Journal of Microbiology and Biotechnology, vol. 23, no. 5, pp. 729-734, 2007.
[12] ABNT, “Associação Brasileira de Normas Técnicas," NBR 7181: Solos: Análise granulométrica conjunta. Rio de Janeiro, Brazil, 1984.

[13] ABNT, "Associação Brasileira de Normas Técnicas," NBR 6459: Solos: determinação do limite de liquidez. Rio de Janeiro, Brazil, 1984.

[14] ABNT, "Associação Brasileira de Normas Técnicas," NBR 7180: Solos: determinação do limite de plasticidade. Rio de Janeiro, Brazil, 1984.

[15] ABNT, “Associação Brasileira de Normas Técnicas," NBR 6508: Massa Específica dos grãos dos solos. Rio de Janeiro, Brazil, 1984.

[16] ABNT, “Associação Brasileira de Normas Técnicas," NBR 7182: Solos: ensaio de compactação. Rio de Janeiro, Brazil, 1986.

[17] Empresa Brasileira de Pesquisa Agropecuária-EMBRAPA, Manual de Métodos de Analise de Solo, Centro Nacional de Pesquisas de Solos, Rio de Janeiro, Brazil, 2nd edition, 1997.

[18] M. O. A. Mariano, Avaliação da retenção de gases em camadas de cobertura de aterros de resíduos sólidos, Tese de Doutorado, Universidade Federal de Pernambuco, Pernambuco, Brazil, 2008.

[19] APHA, Standard Methods for Examination of Water and Wastewater, American Public Health Association, Washington, DC, USA, 19th edition, 1995.

[20] H. P. Caputo, Mecânica dos Solos e Suas Aplicações, Livros Técnicos e Científico, Rio de Janeiro, Brazil, 1988.

[21] J. C. Carvalho, "Propriedades de comportamento de solos tropicais não saturados," in Proceedings of the Simpósio Brasileiro de Solos não Saturados, vol. 2, São Paulo, Brazil, 2004.

[22] J. F. Peng, Y. H. Song, P. Yuan, X. Y. Cui, and G. L. Qiu, "The remediation of heavy metals contaminated sediment," Journal of Hazardous Materials, vol. 161, no. 2-3, pp. 633-640, 2009.

[23] Y. Aş̧̧i, M. Nurbaş, and Y. S. Açikel, "Sorption of Cd(II) onto kaolin as a soil component and desorption of $\mathrm{Cd}$ (II) from kaolin using rhamnolipid biosurfactant," Journal of Hazardous Materials, vol. 139, no. 1, pp. 50-56, 2007.

[24] Y. Aşçi, M. Nurbaş, and Y. S. Açikel, "A comparative study for the sorption of Cd(II) by soils with different clay contents and mineralogy and the recovery of Cd(II) using rhamnolipid biosurfactant," Journal of Hazardous Materials, vol. 154, no. 13, pp. 663-673, 2008.

[25] CETESB, Companhia Ambiental do Estado de São Paulo. Relatório de estabelecimento de valores orientadores para solos e águas subterrâneas no estado de São Paulo. São Paulo, Brazil, 2001.

[26] K. J. Hong, S. Tokunaga, and T. Kajiuchi, "Evaluation of remediation process with plant-derived biosurfactant for recovery of heavy metals from contaminated soils," Chemosphere, vol. 49, no. 4, pp. 379-387, 2002.

[27] C. N. Mulligan, R. N. Yong, B. F. Gibbs, S. James, and H. P. J. Bennett, "Metal removal from contaminated soil and sediments by the biosurfactant surfactin," Environmental Science and Technology, vol. 33, no. 21, pp. 3812-3820, 1999.

[28] B. Dahrazma and C. N. Mulligan, "Investigation of the removal of heavy metals from sediments using rhamnolipid in a continuous flow configuration," Chemosphere, vol. 69, no. 5, pp. 705-711, 2007.

[29] J. W. Neilson, J. F. Artiola, and R. M. Maier, "Characterization of lead removal from contaminated soils by nontoxic soilwashing agents," Journal of Environmental Quality, vol. 32, no. 3, pp. 899-908, 2003. 

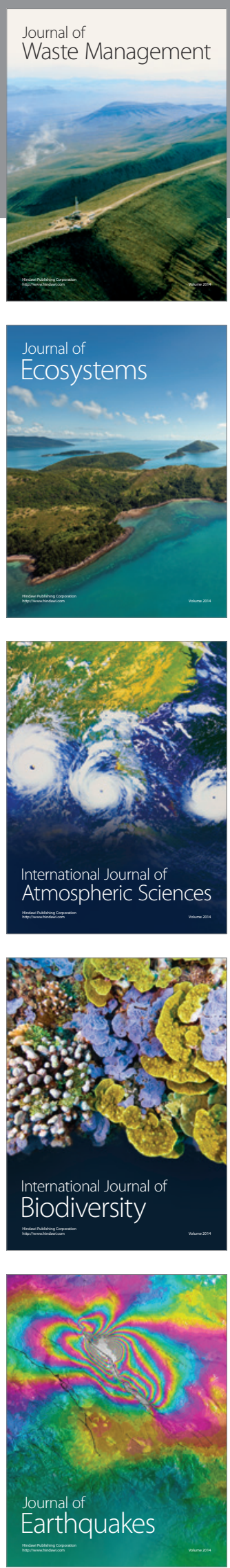
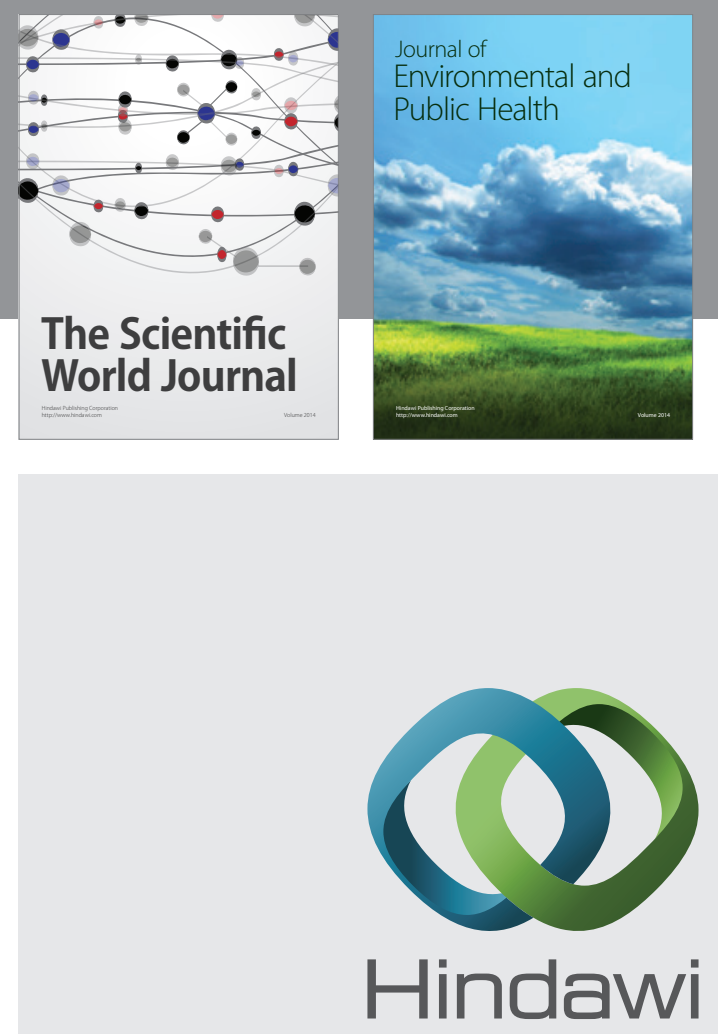

Submit your manuscripts at

http://www.hindawi.com
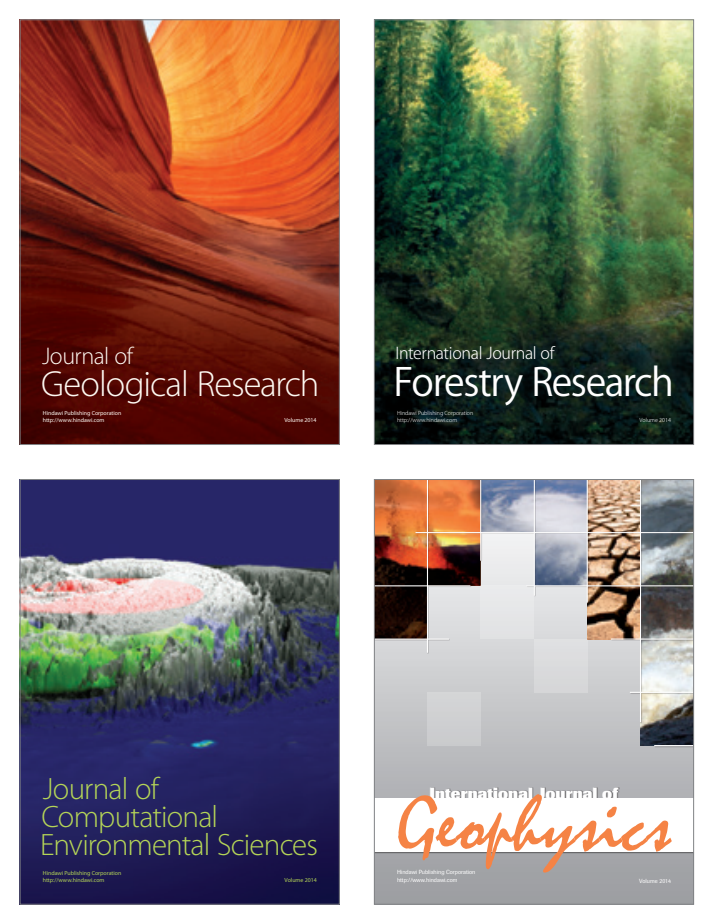
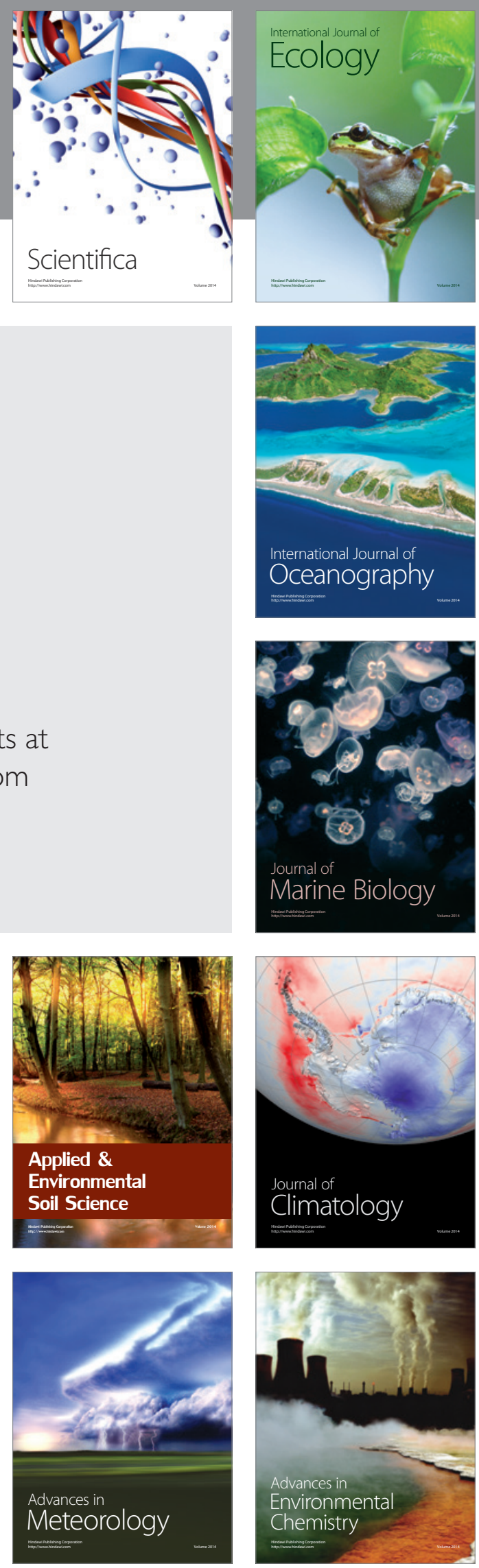